Arab World English Journal (AWEJ) Volume 12. Number2 June 2021

DOI: https://dx.doi.org/10.24093/awej/vol12no2.36

Pp. $540-550$

\title{
Krashen Revisited: Case Study of the Role of Input, Motivation and Identity in Second Language Learning
}

\author{
Francis Bailey \\ University of Kentucky \\ United States
}
Ahmed Kadhum Fahad
University of Thi-Qar
Iraq

Received: 3/7/2021

Accepted: 6/6/2021

Published: 6/28/2021

\section{Abstract:}

Stephen Krashen has a long and enduring legacy in the field of second language acquisition. His "Input Hypothesis" was among the very first attempts to create a coherent theoretical account of second language learning. Krashen argued that learners can acquire language through the process of comprehending it. While elements of his model have been extensively critiqued, this idea has endured and offers teachers a clear mandate to provide learners with abundant opportunities to making meaning of the target language. Utilizing a case study of an English language learner, Krashen's model is challenged and enriched by considering the role that motivation and identity play in learning. Teachers tapping into an important source of learner motivation, role models drawn from the local community or broader society, can inspire and energize students' studies and help them visualize a life in which a second language plays a vital role. Building upon Krashen's idea of the importance of language teachers and programs creating robust reading programs for a sustained engagement with second language print resources, the authors propose to expand his vision and include all manner of multimedia and technologies. However, such a program can only succeed if teachers mediate their learners' social identities and motivations for sustained second language learning.

Keywords: identity, Krashen, linguistic input, motivation, second language development, reading

Cite as: Bailey, F., \& Fahad, A. K. (2021). Krashen Revisited: Case Study of the Role of Input, Motivation and Identity in Second Language Learning. Arab World English Journal, 12 (2) 540 -550. DOI: https://dx.doi.org/10.24093/awej/vol12no2.36 


\section{Krashen Revisited: Case Study of the Role of Input, Motivation and Identity in Second Language Learning}

Optimal input is comprehensible, compelling. There is a lot of it and the context is rich which means the context helps you understand the new input. (Krashen, 2020)

\section{Introduction}

Researchers in second language acquisition (SLA) have provided a consistent message over nearly forty years. The act of comprehending a new language, either through listening or reading, lies at the heart of second language (L2) development. Learners use linguistic input, the oral and written language found in books, movies and a multitude of digital sources, as the raw material to create an understanding of the patterns of a new language system. Crucially, learners must be able to make meaning of this input in order to use it for their own language development.

In this paper, we explore this insight and its implications for language teachers by turning to Stephen Krashen $(1982,1985)$, who proposed a theory of second language acquisition that put comprehended input at the center of language learning. He connected the learning of a second (third, etc.) language to the same cognitive processes that we see in children learning a first language. The comprehension of contextualized input drives language learning. Since the 1980's, Krashen has been a fierce promoter for this perspective and a tireless advocate for the powerful role that a well-designed second language reading program can and should play in an effective language program.

While learning theory can provide a broad and abstract perspective on language development, it is left to teachers to determine what it all means for their particular learners, in specific classroom settings. In this paper, to gain insight into situated language learning and teaching, we explore one of the authors' own experiences of learning English in Iraq. This allows us to examine the intersection of three issues that we believe are central to second language acquisition: comprehended linguistic input, motivation and identity.

In the summer of 2020, the authors participated in a webinar with Stephen Krashen (Fahad \& Krashen, 2020). AUTHOR-2, the organizer of the webinar, and AUTHOR-1, the invited discussant, had an opportunity to talk with Dr. Krashen about his ideas and explore some of their implications for classroom teachers. In this paper, we draw upon this conversation and Krashen's current writings as well as AUTHOR-2's story of his own language development in order to gain insight into the complex and messy business of language learning and teaching.

\section{Revisiting Krashen}

'The best methods are therefore those that supply 'comprehensible input' in low anxiety situations, containing messages that students really want to hear. These methods do not force early production in the second language but allow students to produce when they are 'ready', recognizing that improvement comes from supplying communicative and comprehensible input, and not from forcing and correcting production." (Krashen, 1982, P.7) 
Stephen Krashen has a long and enduring legacy in the field of second language acquisition. His "Input Hypothesis" was the very first attempt to create a coherent theoretical account of second language learning. This theory proposed that learners develop second language competence primarily through the process of comprehending the target language. Krashen believed that much of language learning is subconscious and happens automatically when the learner is focused on meaning (Krashen, 1981). Krashen drew parallels between first language learning by children and second language acquisition by older learners, including adults. He argued that the mental capacities used by children in learning their native language are available for second language learning.

Krashen introduced a short-hand way to think about the type of input that actually promotes second language development: $\mathrm{i}^{+1}$. The symbol " $\mathrm{i}$ " refers to a learner's current stage of language development; the symbol " +1 " is intended to capture the idea that learners require input that is slightly beyond their current proficiency level in the target language. While this concept is problematic for researchers (Ellis, 2012), many language teachers around the world embraced this conception of language learning as it provided a clear mandate for teachers: support your students as they attempt to make sense of new, raw linguistic material in the second language. For educators creating new curriculum, it illuminated a path forward: build a course or language program around students comprehending increasingly complex language structures.

While Krashen's formulation of comprehensible input has proven controversial among linguists, which we discuss below, the idea that linguistic input comprehended by learners drives second language development is central to current theories of second language acquisition (Ellis \& Shintani, 2013; Gass \& Selinker, 2008). The human brain is wonderfully adept at finding patterns and regularities in data of all types, including language. As long as the learner is motivated to attend and make sense of incoming linguistic input, the fundamental condition for second language acquisition has been met. In this scheme, a central role of the language teacher is to support their learners' attempts to make meaning of the new language.

Krashen also posited a component of the theory that he called the "affective filter." If comprehended input drives second language learning, then anything that impedes learners' access to input limits language development. With this component, Krashen introduced the role of learner emotion or "affect" into his theory. The "affective filter" functions metaphorically in this way; when a learner is feeling relaxed and safe, his filter is low and input flows easily and is readily processed. When a learner is feeling stressed, unmotivated or fearful, the affective filter is high and input is blocked or reduced which hinders language acquisition. While this device is simplistic in its mechanistic conception of the role of learner emotions, it did introduce this important variable into a theory of language learning.

Krashen's theory challenged centuries of accepted second language pedagogy. Krashen urged teachers to abandon traditional classroom learning activities such as translation from the second language to student' first language and students memorizing grammar rules, vocabulary lists and instructional dialogues. In their place, Krashen's Monitor Theory proposed that primary learning activities center around learners' engagement with oral or written language. The teacher's primary job is to support students' understanding of these second language texts. 


\section{Challenges to Krashen's Theory}

Several of Krashen's key tenets have been challenged since their publication in early 1980 's. One element of Krashen's theory that has not been embraced by researchers or educators is the idea that language production plays no significant role in language acquisition (Swain,1995). In other words, Krashen has claimed that learners do not develop grammatical competence by speaking and writing. However, SLA researcher, Merrill Swain, cogently argued that language output has multiple functions in language learning, including providing learners with an opportunity to try out their own hypotheses about the new language.

Macky (2012) provides research evidence that suggests learner interaction in the second language can help them negotiate or clarify meaning which also facilitates second language development. Many teachers have been skeptical of the idea that students' language use plays no significant role in learning based upon their own teaching experiences in the language classroom; student language production and use are bound up in complex ways with learner motivation, classroom engagement and the messy process of figuring out how a new language works.

Another problematic element of Krashen's theory has been his formulation of $i^{+1}$. While often embraced by classroom teachers, researchers have rejected the concept as ill-defined and untestable (Ellis, 2012; McLaughlin ,1987). How do we know that understanding a challenging new form in a language is learned when we use context to guess its meaning? What type of unit is " +1 ?" Many teachers around the world have classes of forty students, or more. How would it be possible to effectively teach to all their different $i+1$ levels? Krashen has captured an intuitive sense that learners must be challenged with new linguistic material that is not too far beyond what they can currently handle. However, in terms of a theory of learning, the concept is just too unclear to be tested through research, which is a fatal flaw in a field devoted to empirical research.

\section{Wonderful, Messy Success}

Teachers have continued to embrace the concept of "comprehensible input" as a heuristic device for lesson planning. Krashen's insistence that language production does not play a central role in second language learning has also been, in our estimates, successfully challenged (Swain,1995). We do not intend to revisit these controversies in depth in this paper.

In many ways, Krashen's theory has been a wonderful, messy success. It has provided the fields of second language acquisition and second language teaching with new insights into language learning and the role that teachers can play in that complex process. In the decades since its dissemination, it has inspired spirited debate and countless research studies that explored each claim that Krashen made in his original formulation. While aspects of his theory have been challenged, rejected or modified, his central insight that language input that is comprehended lies at the heart of second language acquisition has been widely accepted in the research field. However, this perspective has never been fully understood and accepted by classroom teachers.

We have come to believe that Krashen's conceptions of second language development would greatly benefit from a focus on issues of learner identity and motivation. His concept of "affective filter" could be viewed as an attempt to explain how motivation factors into language 
development. Low motivation would restrict the amount of input that is comprehended by a learner and, thereby, limits opportunities for engagement with the massive amount of input required for language development. The issue of learner identity and its role in second language development is not addressed by Krashen in the original theory or his subsequent writings.

In the next section of the paper, we explore our belief that identity and motivation are intertwined. These two concepts are central to the efforts of practicing classroom teachers to support and nurture language learning. We begin with a story by one of the authors of this paper of his own journey as a learner of English.

\section{AUTHOR: My English Language Learning Story}

I describe my learning of English as a foreign language as a self-learning journey. In the 1980 's, due to political reasons, English was not very well supported by the educational system in my country, Iraq. The Arab nationalism and anti-colonialism culture that Saddam Hussein and the Ba'ath party advocated for entailed that the English language was related to Western liberalism, the enemy. Due to this and later to the United Nations' sanctions on Iraq, the educational system was deteriorating, and English language teaching and curriculum were very ineffective, resulting in low English levels for almost all Iraqi high school graduates.

In Iraq, English was typically offered at the fifth elementary grade. Our school had no English teachers since most teachers had to join the army at that time. However, since we had to take the Baccalaureate exam at the sixth elementary stage, our school principal assigned us an English teacher who was originally a teacher of history and knew very little about English. I barely passed the 6th grade province-wide exam that qualified me to enter middle school. My English literacy was close to nonexistent with a cursory knowledge of the alphabet and basic grammar patterns.

In 1993, I was sixteen years old with limited English skills and had to pass the second more difficult ministerial Baccalaureate comprehensive exam. I again barely passed. Besides luck in guessing with the multiple-choice questions; I was also fortunate to have been taught with an audio-lingual method. Our teachers coached us to follow clear rules: "If you see the auxiliary BE verb before a blank, choose a verb with "ing," "Memorize lists of possible irregular past forms" and "Memorize a passage for writing the essay section." No communicative component was needed in this exam.

The kick start for real and lasting development of my English skills started after graduating middle school. There was a story behind changing an English "nightmare" into a lovely dream! A one single event made me love English and decide that it would be the primary subject for the rest of my education. The story shows the power of one person to change one's life.

After graduating the third intermediate grade which is a three year school after the elementary stage, I had a GPA that qualified me to enter the Dhi Qar Teachers Training Institute, a five-year program that prepares students to be teachers at the elementary school level. After I finished the third year, it was time to decide on a department that would be the subject of my future profession as a teacher. 
Students had to attend a counseling session to be advised on what department to choose. The choices needed to be either Arabic language, English language, history, math or biological science. At that time, no student liked to go to the English language department as English was considered a difficult subject.

Mr. Ameer Doshi, the head of the English department and the counselor of that session, inspired me by his speech on the importance of English. He told us stories based upon his own life of the role that English has played and the power of English to open up our minds to the broader world. Teacher Ameer was known for his good teaching, kindness, and being close to students. Unlike most other teachers in the school, Mr. Doshi was a strong advocate of students and a big believer in their potential for success. After meeting Mr. Doshi, I started to have an interest in learning English. I became convinced that English was the best fit for me. My knowledge of English, however, was still very low.

As I started my first year in the English department, I was disappointed because I did not understand much of anything from the classes I was taking. I started realizing that there was a major difference between the Arabic language system and the English language systems. I thought I had to start from there. During the summer break of that school year, I spent much time figuring out how to improve my English. There were no computers or internet, and books were as rare as food at that time since the country was under severe UN sanctions (1991-2003). I accidently found an old shabby book in a corner of my mother's room. It was a middle school English textbook and with the aid of some friends, I got another book, a worn-out EnglishArabic dictionary that was compiled by an Iraqi English educator. Backed by my interest, need and influence from my teacher, I became very motivated to read these books. Not only did I read the stories, I also started memorizing all their vocabulary and analyzing their instructional exercises.

I also started realizing that I had a talent that would help me learn English. I made a plan to memorize a list of words every day during that summer and learn some basic English grammar. By chance again, a friend mentioned that he had some English novels and short stories that he found in his late father's home library. He was more than kind to lend me several books in English. Henry James' "A Portrait of a Lady" was my first prey! I could not believe that I was reading such a complicated novel. It took me four months to finish it, and I knew I would have not been able to read it without my bilingual dictionary. At this point I discovered that I had started to forget the meaning of many English words I had blindly memorized. Yet, I also found it was a daily occurrence to not know the meaning of many words that I came across while reading.

Extensive reading was an effective solution to this vocabulary challenge. It benefited me in two ways. First, I was able to store more words in my long-term memory as I read them in context. Second, it motivated my mind to look for strategies or mnemonics in memorizing words. I was good at using the association strategy and other cognitive connections that helped me memorize long lists of words. I think that most of my word reservoir is gained through funny associations of English words with personal experience and events of my life. Getting my eyes accustomed to long periods of reading greatly helped me not only to memorize words in context, but also to gain a sense of the language. As I was writing, I felt that I was unconsciously 
adopting the writing styles and grammatical structures of what I was reading. All in all, I found that it was the combination of the motivation to learn and my active attention to my learning, as well as my burgeoning identity as an elementary English teacher that propelled my fluency as an English learner. It was this intersection that was central to my second language development and love of the English language.

My English language learning journey has given me insight and determined the path that I later took for my education and career. I decided to pursue my MA and later my doctorate in the area of bilingual education. I graduated with my doctorate in second language studies from a U.S university. My goal as an educator is to dedicate my time and expertise to do research, training and other professional development services to enhance second language education in Iraq and elsewhere.

\section{Analysis of the AUTHOR's Story}

Using the story as our data source of a L2 learner experience, we analyzed the story in terms of Krashen's theories and what it reveals about the nature of second language learning.

Motivation, Intrinsic and Extrinsic: The most striking significance of Krashen's theories is his insistence on the power of reading to promote language development. To Krashen, those who read more are distinguished in their achievement of both their first and second languages (Krashen, 2004). However, many educators struggle with finding an answer to the question of how to motivate students to read more and this has not been satisfactorily answered by Krashen. Reflecting on The AUTHOR's story, it can clearly be seen that both intrinsic and extrinsic motivation played vital roles in his learning. The affective filter and the $i+1$ are inadequate to explain the sociocultural aspects surrounding learners' motivation to learn. The Affective Filter Hypothesis states that a student would be limited in their ability to acquire a second language if there were some sort of barrier, such as fear or fatigue, blocking them, even though everything is in their favor to learn it. The 'affect' in the theory's name refers to a student's feelings, motives and mental state. A learner who is tense, anxious, or bored may 'filter out' input, making it unavailable for acquisition" (Lightbown \& Spada, 2006, p. 37). Students' motives and feelings about learning another language greatly affect the way we should instruct our English language classrooms.

In the case with the AUTHOR, we see the power of reading in English as it provided the only readily available source of the second language. However, the limited reading materials, lack of effective English formal education and his low basic literacy skills in English are just a few of the challenges he faced. What looks like "intrinsic motivation" actually has social roots. The AUTHOR's drive to learn English was greatly influenced by his teacher, Mr. Doshi, a model of a successful English learner, as well as family support and encouragement. The AUTHOR's motivation to master English was directly related to his future image of himself as a teacher of English. This resonates well with what Donyei described as a "future L2 self" in which learners" motivation is sparked and sustained by imagining themselves in the future as competent speakers of English (Hadfield \& Dornyei, 2013).

Part of the AUTHOR's success in acquiring his second language was due to the inspiration he got from his teacher, whose speech in that counselling meeting helped eliminate 
the hesitation the AUTHOR had in deciding on which department to go. The affective filter theory offers no explanation on the social factors we saw in the AUTHOR's experience. In his critique of Krashen's theories, Zafar (2009) argues that the affective filter is not adequate to account for larger social factors that impact learning. Krashen did not attempt to explain the many social variables (Block, 2003; Lantolf \& Thorne, 2006) surrounding his theory, leaving it unconvincing when others test it empirically like what we do in this study.

The teacher in the AUTHOR's case offered positive modeling and encouraged higher self-efficacy for his students. According to Zimmerman (2013) self-efficacy and self-regulation often come from observing teachers, followed by the support and encouragement of learners.

Identity: Social identity plays a central role in second language learning (Norton, 2006) and motivation is closely connected to identity and the many sociocultural factors surrounding it. The The AUTHOR went through different stages of identity shaping due to both internal and external motivators. That could be explained in terms of Donyei and Chan's (2013) perspective of identity which he called the 'ought-to L2 Self'. When family and friends began to refer to the AUTHOR as "the translator" or "the teacher," this was a source of encouragement; it also instilled in him a feeling of uneasiness as he sought to be as others perceived him, his "ought to be" self.

That sense of identity led to a higher self-efficacy in his learning which was seen in his learning autonomy and the learning strategies he adopted to cope with the limited resources which were available for him. According to Donyei and Chan (2013), the 'ought-to self' is associated with avoiding negative results which in the AUTHOR's case meant not working hard enough to acquire the English language or not being academically successful.

Learning autonomy: The social-economic and geo-political circumstances in which the AUTHOR lived left him with limited resources to access linguistic input or decent formal learning. Consequently, the AUTHOR's motivation around the "ought-to self" forced him to rely upon self-learning as the only resort and in this case proved effective.

\section{Implications for Classroom Teachers}

Research into second language learning can provide a helpful guide for classroom teachers with insights into human memory and learning processes. However, teachers are often left to themselves to figure out the research's implications for their own students and contexts. In this section, we discuss three powerful implications for classroom teachers that can build upon this research base.

Comprehended Input: Language teachers can greatly enrich their teaching practices by increasing the amount of classroom time devoted to learner comprehension of the target language. The texts, carefully selected for topic and complexity, provide the basic input that learners need to grow their linguistic knowledge and skills. Teachers have two primary responsibilities in these input type lessons. First, they must engage and work with their students to select appropriate second language texts. These may be drawn from a diverse range of options: novels, non-fiction texts, movies, television, radio, audio tapes, social media, computer programs and other types of digital resources. Teachers can help their learners locate authentic or 
pedagogical classroom texts which are carefully controlled for topics suitable for their learners and language that is appropriate for their language proficiencies. This work is done by teachers in the lesson planning phase and in class discussions with students.

Second, teachers must be prepared to facilitate the comprehension of the texts by introducing parallel source(s) of meaning through class discussion, translation, gesture, image, realia and so on. It is critical to keep in mind that it is not the introduction of a text that sparks language learning but the comprehension of that text. In the language classroom, teachers and students can work together, drawing upon whatever local resources are available, to support meaning making (Hall, 2019).

Teachers too often neglect this critical component of classroom learning: meaning making. This is where the art of teaching comes into play. The ability to help one's students comprehend a foreign text draws upon teaching competencies that highlight the particular skills and knowledge that classroom teachers possess of their students' second language proficiency, literacy skills, interests and passions and local community and broader culture in which they live.

Stephen Krashen identified input in second language acquisition as the essential element in the language learning process. He has developed and tirelessly promoted the idea of the power of a well-planned reading program. Krashen believes that reading in a second language is a very significant tool in bilingual education. He proposes a program, Free Voluntary Reading (Krashen, 2011), in which language students gain access to a new linguistic system through extensive reading. When students read in a second language it can increase literacy skills and develop vocabulary and grammatical competence. This program can be used for young or older learners and has two key features: 1) learners select reading materials on topics they have genuine interest in; 2) learners have easy access to these materials.

This type of program is consistent with Krashen's focus on the importance of exposure of language learners to massive amounts of second language input that is comprehensible. This approach is based upon Krashen's belief that the most efficient path to developing second language competence is to draw upon learners' subconscious processing capacities. He refers to this as the "easy way" to learn a language and contrasts this approach to the "hard way" in which learners use conscious processing methods, such as memorizing vocabulary and grammar rules.

We can expand upon Krashen's idea of a reading program and include all manner of multimedia. Teachers and students can navigate together to gain access to the diverse range of language resources that have the potential to capture learners' attention and promote learning.

\section{Teaching Implications}

\#1: Teachers should create, with their students in their language classes and programs, a robust linguistic input program to support second language development.

\#2: Teachers' primary responsibility is to facilitate meaning making as students encounter challenging second language oral or written texts.

\#3: Teachers must continually assess student comprehension in order to determine that students have truly understood class texts. 
The nice thing about these three implications is that the classroom teacher has direct control over each. While nothing can be done in the classroom without the cooperation of students, these elements fall well within the normal practices of teachers, supported by schools and communities. Teachers, with their intimate knowledge of their students, are well positioned to select texts, facilitate meaning making, set up reading programs, and so on. However, the challenge that many teachers face is that a sizable proportion of students are not highly motivated to study second languages. As we saw with the AUTHOR's story, issues of identity and motivation became intertwined in ways that directly impact language development.

Motivating Learners: Teachers have long been in the business of motivating their learners, using a range of rewards and punishments. The AUTHOR's story reveals the ways that apparent intrinsic motivation such as a strong ambition to succeed may have roots in what is usually thought of as extrinsic motivation. Humans are profoundly social beings and even characteristics that are thought to be part of the personality of a person may have originated in the family or broader cultural environment.

The AUTHOR's story reveals both the power of Krashen's theory and its limitations from the point of view of classroom teachers. It is clear that his self-directed reading program was instrumental in his development of English. However, the source of his motivation can be found in the inspirational model his teacher provided and the ways that his identity as a successful English learner positioned him within his own family and community.

\section{Teaching Implications}

\#4: Teachers should tap into an important source of learner motivation: Models drawn from the local community or broader society to inspire and energize students' studies and help them visualize a life in which a second language plays a vital role.

\#5: Teachers should actively engage students in dialogue and reflection around the development of new identities as second language learners and users.

\section{Conclusion}

Language programs in schools around the world are unique in the particular learners enrolled, the cultural context of the school and the particular moment in time the teaching and learning take place. Local classroom teachers are responsible for shaping a learning environment that is effective for their students. They are in debt to Krashen and the many researchers who have contributed to our growing understanding of this enormously complex process.

And yet, teachers must reach beyond these abstract theories and create classes that are effective for their complex, imperfect learners. Krashen's theory points teachers toward a program of massive, comprehended input. The AUTHOR's story suggests ways that social context, including teachers, family and community, play a fundamental role in the learning process by mediating social identity and motivation required for sustained second language learning.

\section{About the Author:}

Dr. Francis Bailey is the Director of the TESL MA Program at the University of Kentucky, U.S. He has conducted research on second language acquisition and challenges faced by English 
learners due to differences between home and community ways of learning and knowing and the academic and social demands of schools. Dr. Bailey focuses on the role that social and cognitive processes play in second language learning and the implications for classroom teachers. https://orcid.org/0000-0002-9558-0751

\section{References}

Block, D. (2003). The social turn in second language acquisition. Georgetown University Press. Dörnyei, Z., \& Chan, L. (2013). Motivation and vision: An analysis of future L2 self images, sensory styles, and imagery capacity across two target languages. Language learning, 63(3), 437-462.

Gass, S. \& Selinker, L. (2008). Second language acquisition: An introductory course, 3rd Edition. New York, NY: Routledge

Ellis, R. ((2012). The study of second language acquisition. Oxford: Oxford University Press.

Ellis, R. \& Shintani, N. (2013). Exploring language pedagogy through second language acquisition research. Abingdon, Oxon: Routledge.

Hadfield, J. \& Dornyei, Z. (2013). Motivating learning. New York: Pearson.

Hall, J. (2019). Essentials of SLA for L2 teachers: A transdisciplinary framework. New York, NY: Routledge.

Krashen, S. D. (1981). Second language acquisition and second language learning (Vol. 2). Oxford: Pergamon Press.

Krashen, S. D, (1982). Principles and practice in second language acquisition. Oxford, Pergamon Press.

Krashen, S. (1985). The input hypothesis: Issues and implications. New York: Longman.

Krashen, S. D. (2004). The power of reading: Insights from the research. Santa Barbara, CA: ABC-CLIO.

Krashen, S.D. (2011). Free voluntary reading. Santa Barbara, CA: ABC-CLIO.

Krashen, S.D. \& Fahad, A. (2020). Krashen Theories on Second Language learning. University of Kentucky. https://youtu.be/eICbusDO9Rk

Lantolf, J.P. \& Thorne, S.L. (2006). Sociocultural theory and the genesis of second language development. Oxford: Oxford University Press.

Lightbown, P., \& Spada, N. M. (2006). How languages are learned. Oxford: Oxford University Press.

Mackey, A. (2012). Input, interaction and corrective feedback in L2 classrooms. Oxford: Oxford University Press.

McLaughlin, B. (1987). Theories of Second-Language Learning. London: Edward Arnold.

Norton, B. (2006). Identity as a sociocultural construct in second language education. TESOL in Context, 16, 22-33.

Swain, M. (1995). Three functions of output in second language learning. In G. Cook and B. Seidlhofer (Eds.), Principle and practice in applied linguistics: Studies in honour of H.G. Widdowson (pp. 125-144). Oxford: Oxford University Press.

Zafar, M. (2009). Monitoring the 'monitor': A critique of Krashen's five hypotheses. Dhaka University Journal of Linguistics, 2(4), 139-146.

Zimmerman, B. J. (2013). From cognitive modeling to self-regulation: A social cognitive career path. Educational Psychologist, 48(3), 135-147. 